\title{
David Raitt
}

This column aims to draw your attention to various interesting Websites which I have come across and which might appeal to you, and to keep you up to date with news and views on Internet trends, developments and statistics. It offers essentially a personal selection rather than comprehensive coverage. Although some sites may not cover products or services available in South Africa, they are included because they may inspire you to either contribute missing data or become an entrepreneur and create a similar local site.

\section{Have I got words for you?}

Global Language Monitor (GLM) documents, analyses and tracks trends in language all over the world, with a particular emphasis upon Global English. Created in 2003 for media analysis functions, the Global Language Monitor is recognised for its expert analysis on language trends and their subsequent impact on politics, culture and business, including the PQ Index/Indicator, analysis of media coverage of major, worldwide events, the rise of Global English and its march to its $1000000^{\text {th }}$ word, the Chinglish Phemomenon, Global yoofSpeak, and many others. Buzzwords and the use of language in many different areas such as fashion, Hollywood, the 2008 US election, dictionaries and the global meltdown are all covered. If you enjoy words then this is a site for you! Find it at http://www.languagemonitor.com/.

\section{Made in Africa}

Some of you may know this site already, but others may not. AfriGadget is a Website dedicated to showcasing African ingenuity. A team of bloggers and readers contribute their pictures, videos and stories from around the continent. The stories of innovation are inspiring. It is a testament to Africans bending the little they have to their will, using creativity to overcome life's challenges. Categories covered include Communication, Energy, Environment, Food, Gadgets, Health, Materials, Recycle \& Reuse, Sanitation, Tools, Toys, Water and more. One recent example is a device called Solar water disinfection (SODIS) that uses solar radiation to destroy pathogenic microorganisms which cause water borne diseases. One of the goals at AfriGadget is to find more stories of African ingenuity. The Grassroots Reporting Project is a plan to find, equip and train more AfriGadget reporters in the field throughout Africa. The network of field reporters will report on stories that are ingenious innovations that are new, or that repurpose existing technology in a new way and that are interesting, practical and solve problems in a demonstrable way (so if you are interested in becoming a reporter then get in contact with them). The Website also has a shop where you can buy articles and gadgets. See what ingenious items have been developed in Africa at http://www.afrigadget.com/.

\section{Visual searching}

There are so many search engines these days - each one offering something different. Searchme claims to be the world's first multimedia search engine. As soon as you start typing a keyword in the search box, categories appear alongside that relate to your query. Choose a category, and you'll see pictures of Web pages that answer your search. You can review these gallery image pages quickly to find just the information you're looking for, before you click on it to go to that actual Website. The list of image pages also appears at the left under Contents to give quicker access to a possibly relevant site and you are also able to refine the topic. Try it for yourself at http://www.searchme.com/. 


\section{Climate change}

Have you ever thought about what the climate might have been like a long time ago? Now you have the possibility to track changes in global conditions over time in various parts of the world. A new Website gives a series of visualisations showing how some of the key indicators of climate change, such as temperature, sea ice extent and carbon dioxide concentrations, have changed in Earth's recent history. From the initial screen, you can select one of the topics and then use a slider to observe the degree of change that has occurred. Global temperature runs from 1885, ice melt from 1979, carbon dioxide emissions from 1979 and sea level from 0-6m. Have a first look at http://climate.jpl.nasa.gov/ClimateTimeMachine/climateTimeMachine.cfm and then carry on to the Global Climate Change Website at http://climate.jpl.nasa.gov/.

\section{Touring the Sistine Chapel}

If you've never toured the Sistine Chapel in St. Peters Church in Rome, then wait no longer. The world's largest gigapixel picture enables you to do it from the comfort of your own home. By means of the panoramic fish-eye camera and simple controls, it is possible to pan around the chapel, look at the ceiling and zoom in to see detail. Right clicking on the mouse gives other interesting perspectives. Gaze in awe at http://photoartkalmar.com/Photoart\% 20Kalmar\%20high\%20res/Gigapixel/Piaristenkircheflash.html. If you want to know more about the technology and see other examples check out http://www.krpano.com/.

\section{Mapping your ancestors}

Many people these days are interested in their roots - their ancestry - and there are numerous sites available to help them with their research. One with a different take on the topic is Ancestral Atlas, which allows you to add your ancestors' life events where they happened and to be able to share that knowledge with others. Over time, as more and more people add their data, Ancestral Atlas will be a site for not only creating a visual data base of your family tree maps but also a primary source for continued research into your family's history. Before you sign up (for free) you can browse around the site to see what others have already mapped. Maybe there is a match with you! Have a look at http://www.ancestralatlas.com/ancestral-atlas-genealogy-mapping-network.php.

And while we're talking about this - also have a look at the Map your Name Website at http://www.mapyourname.com. Claiming to be the global name mapping Website, whatever your name, there will be a place in the world it is most common. That place may be a continent, sometimes a country but very often a very specific region or even city or town whose location can be marked on a map. You can look up surnames or personal names and also see groups of names. Sources include electoral registers in the UK, Australia and Ireland, telephone directories in Italy and Spain, commercial databases in Denmark, Germany and the UK, and names of children in The Netherlands. This is nowhere near global - but it's a start and it gives the origin of names and may be of some use to South Africans wishing to trace European roots. It still has some way to go though - for instance my name is not included!. There are many other surname finding databases on the Web though.

\section{Simply the best}

Web100.com is claimed as your source for the best of the Web. Rankings and reviews guide you to the Web's best sites and resources with categories including arts and culture, business, computing and IT, education, health and family, hobbies, sports and outdoors and tags covering photography, tech, blogs, DIY, style, offbeat, shopping, music and more. The 
top 100 lists, top 10 lists, and other lists help you cut through the Web's clutter and find the information you want. Web100 chooses Websites and online resources based: on their quality; popularity (especially whether the viral nature of the Web increases its value); whether it has won any awards, kudos, or acclaim; and other factors such as the depth and quality of the content; the effectiveness of services and tools; usefulness; design; user interface and usability. Advertisers and sponsors have no role in determining the content of Web100.com's top 100 lists and other editorial features. The bottom line in assessing a site is: Will readers find it useful? Will they be wowed by its services and tools? Will they bookmark it and return to it again and again? Check it out at http://www.web100.com/.

\section{Associating people with organisations}

Muckety is an American site which enriches news stories with interactive maps of the protagonists' networks of influence, that is the relationships between people and organisations. Muckety (the name derives from muckety mucks) was founded in 2006 by a team with years of experience in journalism, technology and online publishing and which produces a daily news and information site based on online databases (enlarged daily), extensive research and old-fashioned journalism. The team strives for accurate, timely, objective journalism and aims to be nonpartisan. Whatever news story you are after you are provided with a kind of mental map - a web of connections. With people or organisations in each connected box. Click on any one of these to find another web - click on the menu at left (or right click) for more options including information about the various boxes clicked. You can carry out a normal search to get an association map or you can select one of several categories. To view the news in a different manner, have a look at

http://news.muckety.com/.

\section{What the police think}

NightJack - an English detective - is the revealing and depressing blog of an anonymous British policeman (thus spake The Economist). Apparently he was inspired by another police blog called Inspector Gadget (http://inspectorgadget.wordpress.com/) - which seems to be one of several others. However, the blog by Jack Night, a serving police officer, has just won the Special Prize for Blogs. The judges said: 'Getting to grips with what makes an effective blog was intriguing - at their best, they offer a new place for politics and political conversation to happen. The insight into the everyday life of the police that Jack Night's wonderful blog offered was - everybody felt - something which only a blog could deliver, and he delivered it brilliantly. It took you to the heart of what a policeman has to do - by the first blogpost you were hooked, and could not wait to click onto the next one. Jack invites comments on his blogs - so if you want to (voluntarily) read what the police think in the UK, then move along to http://nightjack.wordpress.com/.

\section{About the author}

Dr David Raitt is senior technology transfer officer with the European Space Agency in the Netherlands. His work involves finding applications for space technologies in non-space sectors, particularly those useful for improving everyday life. An information scientist by education and training, David is also editor of The Electronic Library and chairman of the Internet Librarian International conferences. 